\title{
Financial Development in Developing Countries and Its Impact on Economic Growth between 2008 and 2017
}

\author{
Khuloud Mohammed Alawadhi ${ }^{1}$, Nour Mansour Alshamali ${ }^{1} \&$ Mansour Mohamed Alshamali $^{1}$ \\ ${ }^{1}$ Insurance and Banking Departement, Public Authority for Applied Education and Learning, Kuwait \\ Correspondence: Khuloud Mohammed Alawadhi, Assistanat Professor, Insurance and Banking Departement, Public \\ Authority for Applied Education and Learning, Kuwait.
}

Received: October 22, 2021

Accepted: November 12, 2021

Online Published: November 16, 2021

doi:10.5430/afr.v10n4p50

URL: https://doi.org/10.5430/afr.v10n4p50

\begin{abstract}
This article examines how the level of financial development has changed in the ten years between 2008 and 2017 in connection to the most significant events in the global economy and finance and how financial development has influenced economic growth in developing countries. The study measures financial development following the World Bank (2020) approach and using indicators of financial access, financial depth, financial efficiency and financial stability, corresponding to financial institutions and financial markets. Based on a two-way fixed effects model, we find that financial development has positively and significantly contributed to economic growth in these countries during the ten years between 2008 and 2017, through increased access of individual consumers and firms to financial products and services. Other variables such as the depth, efficiency and stability of financial institutions and markets do not correlate significantly with the economic growth of developing countries between 2008 and 2017 . This paper concludes that the access to financial institutions for individuals living in developing nations is favourably and significantly connected to economic growth in these countries.
\end{abstract}

Keywords: financial development, developing countries, economic growth, financial access, financial depth, financial efficiency, financial stability

\section{Introduction}

\subsection{The Importance of Financial Development in Developing Countries}

The level of financial development has great importance for a country. A vast body of data shows that the growth of the financial sector has a significant impact on economic development (Erdoğan et al., 2020; Ibrahim \& Alagidede, 2018). It supports economic growth through capital accumulation and technical advancement by raising the savings rate (Kaur et al., 2017; Quartey, 2008; Wang et al., 2017), mobilizing and pooling funds (Quartey, 2008), creating investment information (He et al., 2019), enabling and promoting foreign capital inflows (Adeniyi et al., 2015; Mhango, 2019; Qamruzzaman \& Jianguo, 2020), and optimizing capital allocation (Xu et al., 2021).

Moreover, countries with more developed financial systems tend to expand faster over time (Čihák et al., 2012), and a significant body of data shows that this impact is causal in the sense that financial development is not just a by-product of economic expansion but it contributes to it (Ouyang \& Li, 2018).

Furthermore, financial development decreases poverty and inequality by improving access to financing for the poor and vulnerable groups, enabling risk management by lowering their sensitivity to shocks, and boosting investment and productivity, which leads to greater revenue production (Wilson et al., 2012).

This subject is especially relevant at the moment because the aftermath of the 2008-2009 global financial crisis and the problems caused by the COVID-19 epidemic, among other factors, have made it difficult for developing nations to obtain financial services and build their financial institutions (Nastu et al., 2021). Also, from a regulatory perspective, the global financial system nowadays is so interconnected that regulatory changes affect not only advanced but also developing countries (World Bank, 2020).

This research topic is particularly urgent because if the evolution of financial development and its impact on economic growth are not investigated for low-income countries, two negative outcomes may result. One is that interest groups in high-income countries may push for financial development as a result of globalization that is not in the best interest or the necessary areas of low-income countries (Mishkin, 2009; Yang, 2019) or financial 
development may not happen at all for these countries (Haseeb et al., 2019). Also, this study is the next logical step in the line of research since most research studies focus on the level of financial development in developed economies and so there is a gap in the literature at the moment around the impact of financial development on economic growth in low-income countries.

The research questions of this paper have, therefore, been formulated as follows:

RQ1. How did the level of financial development evolve in developing countries between 2008 and 2017 ?

RQ2. What was the impact of financial development, measured as financial access, financial depth, financial efficiency and financial stability, on economic growth in developing countries between 2008 and 2017 ?

\subsection{Exploring the Determinants of Financial Development}

This paper uses the World Bank's understanding of financial development, which includes several indicators such as (1) the size of financial institutions and markets (financial depth), (2) the degree to which individuals can and do use financial services (access), (3) the efficiency of financial intermediaries and markets in intermediating resources and facilitating financial transactions (efficiency), and (4) financial institution and market stability (stability) (Klapper, 2015; World Bank, 2021).

Since a country's financial sector includes a wide range of financial institutions, markets, and products, these estimates are imprecise and may not encompass all elements of financial development. To assess financial progress throughout the world, the World Bank's Global Financial Development Database created a comprehensive yet relatively simple conceptual $4 \times 2$ framework. This approach provides four sets of proxy characteristics that characterize a healthy financial system: financial depth, access, efficiency, and stability (World Bank, 2021). These four characteristics are then measured for the financial sector's two key components, namely financial institutions and financial markets, as shown in Table 1 below, which includes some of the most relevant indicators for each category of financial development:

Table 1. Measures of financial development

\begin{tabular}{|c|c|c|}
\hline & Financial Institutions & Financial Markets \\
\hline Depth & $\begin{array}{l}\text { - Private Sector Credit to GDP } \\
\text { - Financial Institutions' asset to GDP } \\
\text { - } \mathrm{M} 2 \text { to GDP } \\
\text { - Deposits to GDP } \\
\text { - Gross value added of the financial } \\
\text { sector to GDP }\end{array}$ & 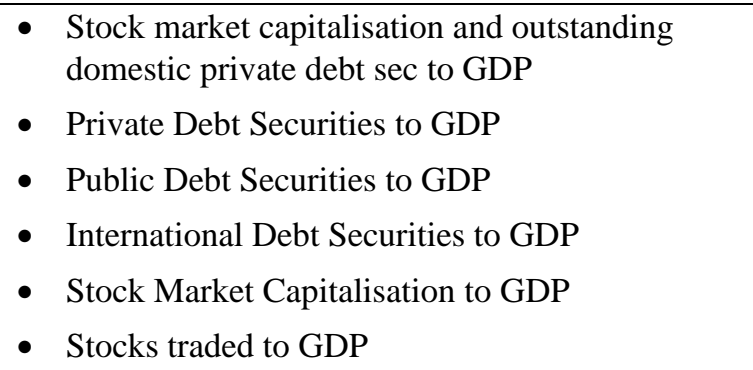 \\
\hline Access & $\begin{array}{l}\text { - Accounts per thousand adults } \\
\text { (commercial banks) } \\
\text { - Branches per 100,000 adults } \\
\text { (commercial banks) } \\
\text { - \% Of people with a bank account (from } \\
\text { user survey) } \\
\text { - \% Of firms with a line of credit (all } \\
\text { firms) } \\
\text { - \% Of firms with a line of credit (small } \\
\text { firms) }\end{array}$ & 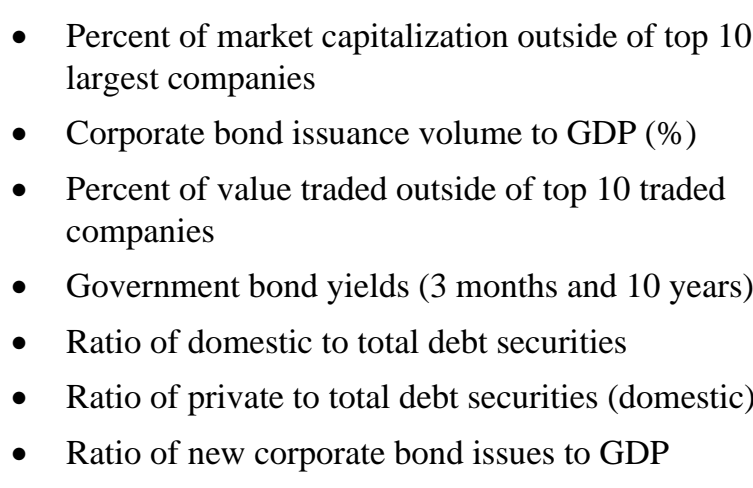 \\
\hline Efficiency & 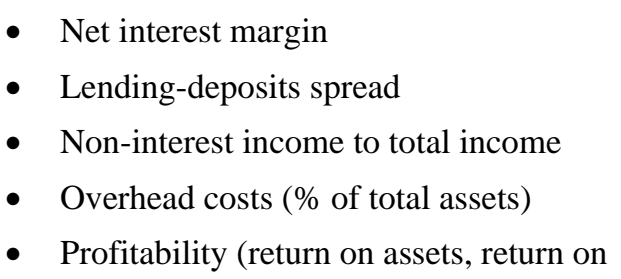 & $\begin{array}{l}\text { - } \text { Turnover ratio for stock market } \\
\text { - } \text { Price synchronicity (co-movement) } \\
\text { - } \text { Private information trading } \\
\text { - } \\
\text { - } \\
\text { - } \text { Liquice impact } \\
\text { Lity/transaction costs }\end{array}$ \\
\hline
\end{tabular}




\section{equity)}

- Boone indicator (or Herfindahl or H-statistics)

\section{Stability}

- Z-score

- Capital adequacy ratios

- Asset quality ratios

- Liquidity ratios

- Bank cost to income ratio (\%)

- Others (net foreign exchange position to capital, etc.)
- Quoted bid-ask spread for government bonds

- Turnover of bonds (private, public) on the securities exchange

- Settlement efficiency

- Volatility (standard deviation/average) of stock price index, sovereign bond index

- Skewness of the index (stock price, sovereign bond)

- Vulnerability to earnings manipulation

- Price/earnings ratio

- Duration

- Ratio of short-term to total bonds (domestic, international)

- Correlation with major bond returns (German, US)

Note. Source: World Bank (2021)

\subsection{Conceptual Framework of Research}

The concept of financial development has been defined by Čihák et al. $(2013$, p. 6) as the improvement in the quality of five key financial functions: (1) gathering and processing information about potential investments and allocating capital based on these assessments; (2) monitoring individuals and firms and exercising corporate governance after capital allocation; (3) facilitating risk trading, diversification, and management; (4) mobilizing and pooling savings; and (5) facilitating the exchange of goods, services, and financial instruments. This conceptualisation of financial development is the basis for the World Bank's classification of financial development indicators under the categories of financial depth, access, efficiency and stability which we adopted in this paper as well. The authors used data on 205 economies for the period from 1960 to 2010 to build the Global Financial Development Database, which is one of the most relevant benchmarks for financial development (Čihák et al., 2013).

Also, economic growth has been defined by numerous researchers who also theorised the concept (Adams, 2004; Daly, 1987; Kaldor \& Mirrlees, 1971; Popkova, 2018; Scott, 1991). In this paper, we use the concept of economic growth as the increase in real national output, which is based on Fisher's (1930) concept of real income. Finally, the concept of developing countries has been used in this study based on the understanding and classification of the World Bank and corresponding to low-income countries. According to the World Bank (2021), countries are classified based on their GNI per capita. The countries with GNI per capita as of 2020 below or equal to $\$ 1,045$ are low-income countries, those with GNI per capita between $\$ 1,046$ and $\$ 4,095$ are lower-middle-income countries, upper-middle-income with GNI per capita between $\$ 4,096$ and $\$ 12,695$, and high-income countries with GNI per capita of $\$ 12,696$ or more (World Bank, 2021).

\subsection{Literature Review}

Other academics that have lately examined the issue of financial growth in developing countries include Ezeibekwe (2020), Taivan and Nene (2016), and Bist (2018), among others. The main findings of these three studies have been presented below, followed by their correspondence with this paper.

Based on data from 1980 to 2018 for 69 developing countries in Sub-Saharan Africa, the Middle East and North Africa, East and South Asia, Latin America, and the Caribbean, Ezeibekwe (2020) examines the determinants of financial development, with an emphasis on economic, political, institutional, socio-cultural, and geographical factors. The lag of real gross domestic product, as well as wide money, bank credit, and financial sector credit, are used to create a financial development index, with the last three being represented as a percentage of GDP (Ezeibekwe, 2020).

The findings of Ezeibekwe's (2020) study show that differences in financial development levels across countries and regions are explained by national income, trade openness, indices of political stability and Polity 2 (a democracy score), perception of corruption, the predominant religion in the countries, and geographical factors such as territorial access to the sea. Those with a high perceived level of corruption have a lower level of financial development, whereas countries with a low perceived level of corruption have a lower level of financial development (Ezeibekwe, 
2020).

Taivan and Nene (2016) investigated the relationship between financial development and economic growth in ten Southern African Development Community (SADC) nations from 1994 to 2013. Using vector autoregression (VAR) to conduct Granger causality tests of the relationship between financial development and economic growth (Taivan $\&$ Nene, 2016). The findings of Taivan and Nene (2016) support two of the three major theories on the relationship between financial development and economic growth, namely the supply leading hypothesis (financial development drives economic growth or positive causality); and the demand following response (economic growth causes financial development or reverse causality). Their empirical findings indicate that when broad money (BM) and direct credit (DC) are employed as indicators of financial development, there is evidence of demand following response in 50 per cent and 60 per cent of the samples, respectively (Taivan \& Nene, 2016). When BM and DC were employed to quantify financial development, the results revealed that financial development induced economic growth in 20 per cent and 30 per cent of the samples, respectively (Taivan \& Nene, 2016). However, when BM and DC were employed to gauge financial development, no evidence of causation was found in 30 per cent and 10 per cent of the nations, respectively (Taivan \& Nene, 2016).

Bist (2018) examined the long-run link between financial development and economic growth in 16 low-income countries from 1995 to 2014 using panel unit root and panel cointegration analysis. Using fully modified and dynamic OLS techniques, the estimation of the relationship between financial development and economic growth shows that there is a cross-sectional dependency across nations (Bist, 2018). Pedroni's (1997) panel cointegration study offers strong support for the idea that financial development and economic growth have a long-run cointegrating connection and, according to long-run panel estimates, financial development has a favourable and considerable influence on economic growth (Bist, 2018).

However, there are significant differences between the extant literature and the current study in terms of the research questions and research methods. Ezeibekwe (2020) investigated the economic, political, institutional, socio-cultural, and geographical factors underlying financial development in developing countries, whereas the current study focuses solely on financial development as measured by indicators such as financial depth, access to financial services, and the efficiency and stability of financial institutions. Taivan and Nene (2016) and Bist (2018) also differ from the current paper's recommended methodology in that they examine financial development and economic growth in terms of the causality between the two concepts and cointegration, respectively.

Another relevant study on the relationship between financial development and economic growth in developing countries, without testing for causality, is the research by Dawson (2008) who tests the hypothesis that empirical research mainly supports the notion that financial development promotes economic growth in developing nations, while there is some evidence to the reverse. Using yearly panel data for 44 developing nations from 1974 to 2001, Dawson (2008) re-examined this relationship. Three sources-of-growth equations are calculated, all of which are derived from aggregate production functions: two are theoretically consistent, while the third employs a common proxy (DEPTH) for financial development. Theoretically-coherent models indicate a positive and statistically significant link between financial development and economic growth, but the proxy version shows the inverse. Dawson (2008) also demonstrated that accurately measuring financial progress proves to be essential for policy recommendations.

Moreover, Estrada et al. (2011) argued that stable and efficient financial systems including banks, equities markets, and bond markets, that route money to its most productive uses, according to economic theory, are advantageous to economic growth. Also, because the efficiency of investment tends to outweigh the quantity of investment as the driver of growth in the area, sound and efficient financial systems are especially crucial for maintaining growth in emerging Asia (Estrada et al., 2011). According to the data analysed by the authors, the region's financial systems have gotten increasingly complex and diverse since the early 1990s. Estrada et al. (2011) conducted a more formal econometric study on a panel data set of 125 countries and found that financial development had a substantial beneficial influence on growth, particularly in emerging countries. Estrada et al. (2011) found that the influence of financial development on regional growth is not significantly different from that of other regions and that the impact has diminished since the Asian financial crisis. Overall, the data suggest that additional financial sector expansion is important for sustaining emerging Asia's growth in the post-crisis period. However, the major role of financial sector development in growth is anticipated to change away from mobilizing funds and therefore increasing investment volume and toward improving investment efficiency and thereby contributing to greater overall productivity, based on the study by Estrada et al. (2011).

The studies by Dawson (2008) and Estrada et al. (2011) are relevant and helpful for the current research since they 
offer insights into the relationship between financial development and economic growth in developing countries. The authors, however, have a different understanding of the concept of financial development and that of developing countries compared to this article and they use different research methods. Nevertheless, they serve as a solid starting point for this research.

Nevertheless, the current literature on the topic of financial development and economic growth is rather limited, which is surprising, especially when using a financial interpretation of the concept of financial development, as explained above in the conceptual framework section and updated with more recent data. We find a gap in the present literature based on the critical literature analysis done above.

Our research contributes to the existing literature by examining a popular subject, that of financial development, on a slightly less popular data sample, of developing countries since most studies focus on the nexus financial development economic growth. Also, this paper examines the level of financial development, during the ten years, between 2008 and 2017. The section below describes the data collection process and the research method we used in this study.

\section{Method}

\subsection{Data Sourcing}

The information was gathered from the World Bank's website, which contains information on Global Financial Development for developing nations. These data have been collected, cleansed, and then analysed using R software.

The timeframe 2008-2017 was chosen since it encompasses the years following the global financial crisis as well as the most current data available until 2017. The emphasis of this article has been set as a sample of developing nations since events having a large financial impact tend to have a more serious and long-lasting impact in developing countries. Furthermore, the suggested study is exploratory, since it does not begin with any pre-established ideas about how the selected developing nations' financial growth has progressed. Nevertheless, there is an expectation, based on the extant literature, that the level of financial development measured here for the low-income counties is positively linked with the economic growth of these countries.

The database for this quantitative analysis in this study includes 25 developing or low-income countries. These are located predominantly in Africa (Burkina Faso, Burundi, Central African Republic, Chad, the Democratic Republic of the Congo, Eritrea, Ethiopia, Gambia, Guinea, Guinea-Bissau, Liberia, Madagascar, Malawi, Mali, Mozambique, Niger, Rwanda, Sierra Leone, Somalia, South Sudan, Sudan, Togo, and Uganda) but also in Asia (Afghanistan and the Republic of Yemen).

\subsection{Research Method}

For the selected nations, the data collected and organised yearly and by country will be examined using a two-way fixed effects model. We draw on previous studies that used comparable quantitative methods of analysis, such as the study by Ezeibekwe (2020), and we show that this technique of analysis enables an objective quantitative examination of the indicators chosen for financial development.

The variables selected to estimate the model include GDP growth expressed in yearly percentage points, and indicators of financial development selected from the four classes of depth, access, efficiency and stability for both financial institutions and financial markets, as shown in Table 1 above, following the World Bank methodology. Constrained by the availability of data for developing countries in the selected timeframe, each of the $4 \times 2$ categories below has a different number of indicators, as shown in Table 2 below. For each of the eight financial development indicators, aggregates have been calculated that will serve as explanatory variables in the regression analysis model. 
Table 2. Selected Indicators of Financial Development

\begin{tabular}{|c|c|c|}
\hline & Financial Institutions & Financial Markets \\
\hline Depth & $\begin{array}{l}\text { - Central bank assets to GDP (\%) } \\
\text { - Deposit money bank assets to deposit money bank } \\
\text { assets and central bank assets (\%) } \\
\text { - Deposit money banks' assets to GDP (\%) } \\
\text { - Domestic credit to private sector (\% of GDP) } \\
\text { - Financial system deposits to GDP (\%) } \\
\text { - Insurance company assets to GDP (\%) } \\
\text { - Life insurance premium volume to GDP (\%) } \\
\text { - Liquid liabilities to GDP (\%) } \\
\text { - Mutual fund assets to GDP (\%) } \\
\text { - Nonbank financial institutions' assets to GDP (\%) } \\
\text { - Non-life insurance premium volume to GDP (\%) } \\
\text { - Pension fund assets to GDP (\%) } \\
\text { - Private credit by deposit money banks to GDP (\%) }\end{array}$ & $\begin{array}{l}\text { - Gross portfolio debt liabilities to GDP } \\
(\%) \\
\text { - Gross portfolio equity assets to GDP (\%) } \\
\text { - Gross portfolio equity liabilities to GDP } \\
(\%) \\
\text { - International debt issues to GDP (\%) } \\
\text { - Outstanding domestic private debt } \\
\text { securities to GDP (\%) } \\
\text { - Outstanding domestic public debt } \\
\text { securities to GDP (\%) } \\
\text { - Outstanding international private debt } \\
\text { securities to GDP (\%) } \\
\text { - Outstanding international public debt } \\
\text { securities to GDP (\%) } \\
\text { - Stock market capitalization to GDP (\%) } \\
\text { - Stock market total value traded to GDP } \\
\text { (\%) } \\
\text { - Syndicated loan average maturity (years) } \\
\text { - Syndicated loan issuance volume to GDP } \\
\text { (\%) }\end{array}$ \\
\hline Access & $\begin{array}{l}\text { - Account at a formal financial institution (\% age } 15+\text { ) } \\
\text { - Account used for business purposes (\% age } 15+\text { ) } \\
\text { - Account used to receive government payments ( } \% \text { age } \\
15+\text { ) } \\
\text { - Account used to receive remittances ( } \% \text { age } 15+\text { ) } \\
\text { - Account used to receive wages ( } \% \text { age } 15+\text { ) } \\
\text { - ATMs per } 100,000 \text { adults } \\
\text { - Bank accounts per } 1,000 \text { adults } \\
\text { - Bank branches per } 100,000 \text { adults } \\
\text { - Checks used to make payments ( } \% \text { age } 15+\text { ) } \\
\text { - Corporate bond average maturity (years) } \\
\text { - Corporate bond issuance volume to GDP (\%) } \\
\text { - Credit card (\% age } 15+\text { ) } \\
\text { - Debit card (\% age } 15+\text { ) } \\
\text { - Depositing/withdrawing at least once in a typical } \\
\text { month (\% age } 15+\text { ) } \\
\text { - Electronic payments used to make payments ( } \% \text { age } \\
15+\text { ) } \\
\text { - Firms identifying access to finance as a major } \\
\text { constraint (\%) } \\
\text { - Firms not needing a loan (\%) } \\
\text { - Firms using banks to finance investments ( } \% \text { ) }\end{array}$ & $\begin{array}{l}\text { - Investments financed by equity or stock } \\
\text { sales }(\%) \\
\text { - Market capitalization excluding top } 10 \\
\text { companies to total market capitalization } \\
(\%) \\
\text { - Nonfinancial corporate bonds to total } \\
\text { bonds and notes outstanding }(\%)\end{array}$ \\
\hline
\end{tabular}


- Firms using banks to finance working capital (\%)

- Firms whose recent loan application was rejected (\%)

- Firms with a bank loan or line of credit (\%)

- Firms with a checking or savings account (\%)

- Investments financed by banks (\%)

- Loan from a financial institution in the past year $(\%$ age $15+)$

- Loan from a private lender in the past year (\% age $15+)$

- Loan from an employer in the past year (\% age 15+)

- Loan from family or friends in the past year (\% age $15+)$

- Loan in the past year (\% age $15+$ )

- Loan through store credit in the past year (\% age $15+$ )

- Loans requiring collateral (\%)

- Mobile phone used to pay bills (\% age $15+$ )

- Mobile phone used to send money (\% age $15+$ )

- Saved any money in the past year (\% age $15+)$

- Saved at a financial institution in the past year (\% age 15+)

- Saved using a savings club in the past year (\% age $15+)$

- Account at a formal financial institution (\% age 15+)

- Small firms with a bank loan or line of credit (\%)

- Value of collateral needed for a loan (\% of the loan amount)

- Working capital financed by banks (\%)

Efficiency - Bank cost to income ratio (\%)

- Stock market turnover ratio (\%)

- Bank lending-deposit spread

- Bank net interest margin (\%)

- Bank noninterest income to total income (\%)

- Bank overhead costs to total assets (\%)

- Bank return on assets (\%, after-tax)

- Bank return on assets (\%, before tax)

- Bank return on equity (\%, after-tax)

- Bank return on equity (\%, before tax)

- Credit to government and state-owned enterprises to GDP $(\%)$

Stability - Gross portfolio debt assets to GDP (\%)

Note. Source: Author's analysis based on World Bank (2021)

An important limitation of the selected data is the fact that there are many gaps, especially around the depth, access, efficiency and stability of financial markets but also stability of financial institutions in the developing countries. This is expected in the selected countries since their financial markets are still developing, however, the fact that there is no data available for any indicator on the stability of financial markets is a major limitation that could impact the accuracy of the model. 


\subsection{Research Hypotheses}

The following research hypotheses have been formulated corresponding to each of the two research questions of this study:

H1. The level of financial development had an increasing trend for developing countries between 2008 and 2017. The null (H0) hypothesis is that financial development decreased in developing countries in the selected period. This hypothesis will be tested based on graphical analysis and data interpretation.

H2. Financial development had a positive and statistically significant impact on economic growth during 2008 and 2017. The null hypothesis is that financial development either had a negative impact on economic growth, measured through either one of the following variables: financial institutions access, financial institutions depth, financial institutions efficiency, financial institutions stability, financial markets access, financial markets depth, financial markets efficiency or it did not have a significant impact on economic growth through either one of the seven variables above.

\subsection{Regression Model}

The linear regression model which we have estimated based on the data described above can be written using the equation below and has the economic growth of developing countries measured by real GDP growth as the dependent variable and the aggregate measures for financial development, namely financial institutions access, depth, efficiency and stability and financial markets access, depth and efficiency as explanatory variables.

Each independent variable has been computed as the aggregate of the corresponding indicators by calculating their average, hence each indicator has equal weight within the independent variables. For instance, the independent variable FM_access has been computed as the average of investments financed by equity or stock sales, market capitalization excluding top 10 companies to total market capitalization and nonfinancial corporate bonds to total bonds and notes outstanding. Each of these three indicators has an equal weight of 33\% each within the FM_access variable. For other independent variables, the weight of the indicators varies based on their number. Equal weights for each indicator cannot be ensured since this would mean using the minimum number of indicators for each independent variable, which is equal to one.

Moreover, country fixed effects and year fixed effects have been included to account for country and time idiosyncrasies.

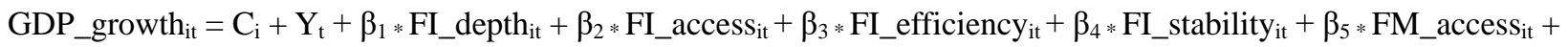

$$
\begin{aligned}
& \beta_{6} * \text { FM_depth }{ }_{\text {it }}+\beta_{7} * \text { FM_efficiency }{ }_{i t}+\varepsilon_{\text {it }}
\end{aligned}
$$

for $i=1,2, \ldots 25$ representing the 25 countries included in the data sample, and $t=2008,2009, \ldots 2017$ representing the ten years between 2008 and 2017. Country and time fixed effects allow for flexible accounting of both country-specific (but time-invariant) and time-specific (but country-invariant) unobserved confounders (Imai \& Kim, 2021).

In the model illustrated in equation (1), the dependent variable, GDP_growth $\mathrm{i}_{\mathrm{i}}$, varies both with the country and time, $\mathrm{C}_{\mathrm{i}}$ is the country fixed effect, $\mathrm{Y}_{\mathrm{t}}$ is the year fixed effect, FI_depth ${ }_{\mathrm{it}}$, FI_access $\mathrm{s}_{\mathrm{it}}$, and FI_efficiency $\mathrm{it}_{\mathrm{it}}$, and are the financial institutions' depth, access, efficiency and stability variables which vary by country and year, FM_accessit, FM_depth ${ }_{i t}$, and FM_efficiency ${ }_{i t}$ are the financial markets access, depth and efficiency variables which vary by country and year, and $\varepsilon_{\mathrm{it}}$ is the error term which also varies by country and year.

\section{Results}

\subsection{Analysis of the Financial Development in Developing Countries between 2008 and 2017}

The level of financial development analysed for the selected 25 countries has been illustrated in Figures 1-7 below, each showing how the access, depth, efficiency and stability of financial institutions, and the access, depth and efficiency of financial markets have evolved between 2008 and 2018.

In terms of the financial access of institutions in the selected developing countries, these showed a variation between 0.5 and 118.8, representing the aggregate index, incorporating all measures of financial institutions' access. Between 2008 and 2017, the highest increase in the access of financial institutions to financial products and services was registered in Togo in the year 2016, reaching a level of 118 points, although this was preceded and then followed by rapid drops below the level of 30 points. 


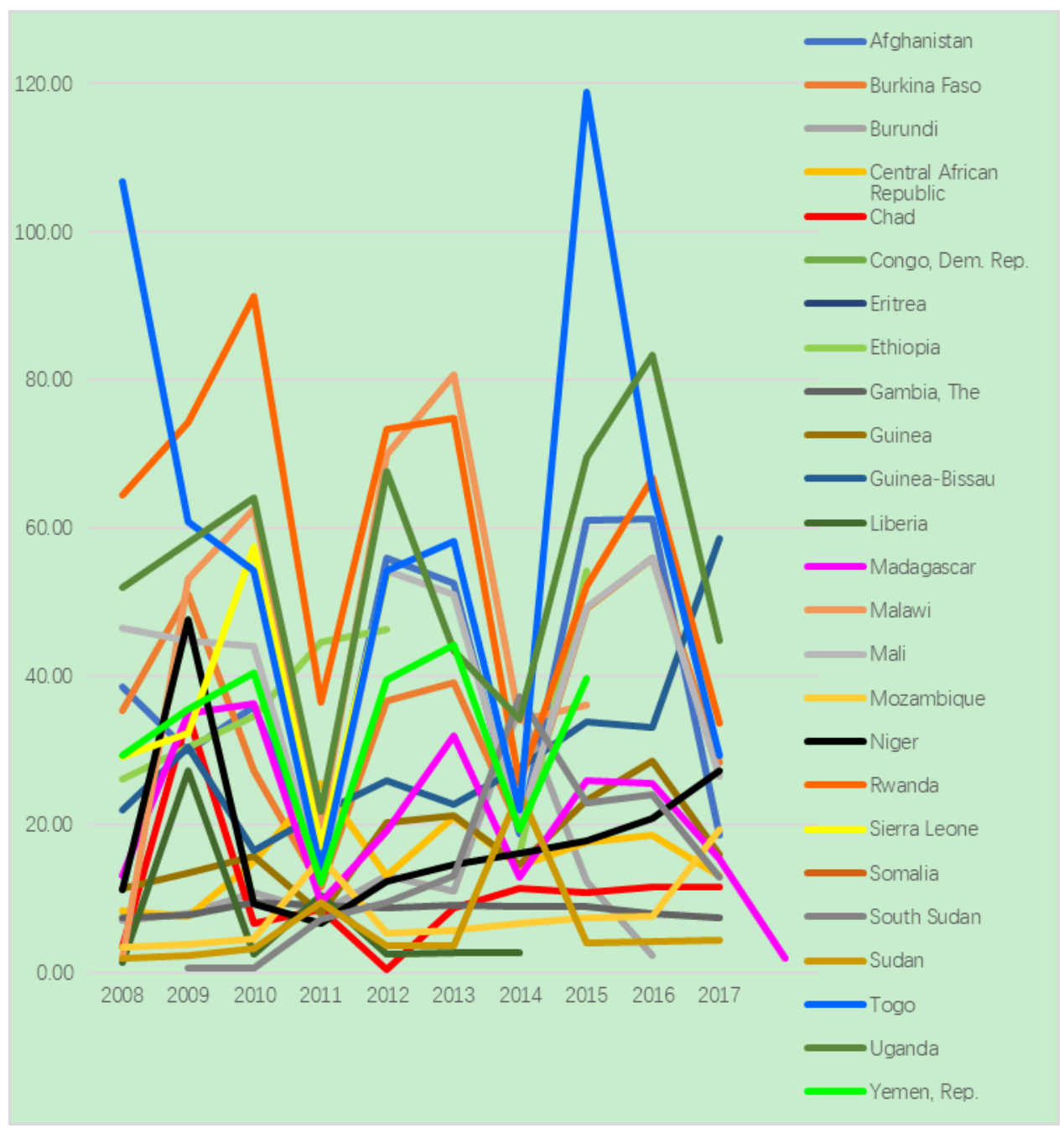

Figure 1. Financial Institutions Access, 2008-2017

Note. Source: Author's analysis based on World Bank data (2021)

Regarding the depth of financial institutions, which means the size of the financial sector relative to the economy of each country (Imam \& Kolerus, 2013), Liberia significantly distanced itself from the other countries with the highest levels of financial institutions' depth. As shown in Figure 2 below, Liberia's depth of financial institutions grew steadily between 2008 and 2014, reaching a peak at 489.5 points, yet this was followed by a massive drop in the following two years, potentially due to the political instability of the country (BBC, 2018). 


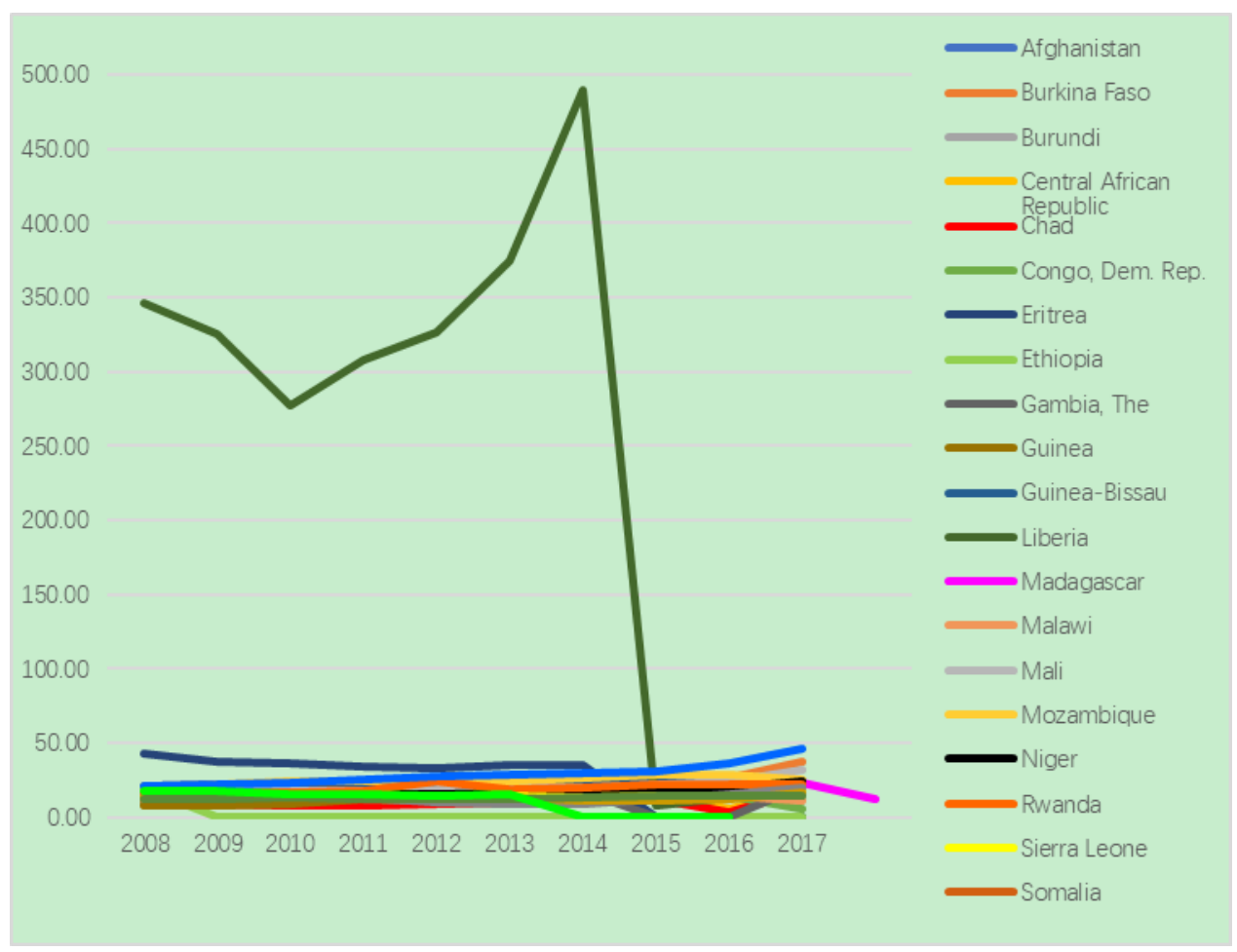

Figure 2. Financial Institutions Depth, 2008-2017

Note. The data has been compiled by the author based on World Bank data (2021)

Figure 3 below shows the evolution in the efficiency of financial institutions indicating an average increase of 20.32 cumulated growth across years and countries, which is great progress. However, as with the other indicators, there is great variation from one country to another and across years. For instance, Eritrea showed the highest increase between 2008 and 2009, immediately after the start of the global financial crisis, followed by a significant drop in the level of financial institutions' efficiency in the next four years and a lack of data between 2015 and 2017. Most countries had a positive evolution around the efficiency of their financial institutions with a modest standard error of only 0.433 . 


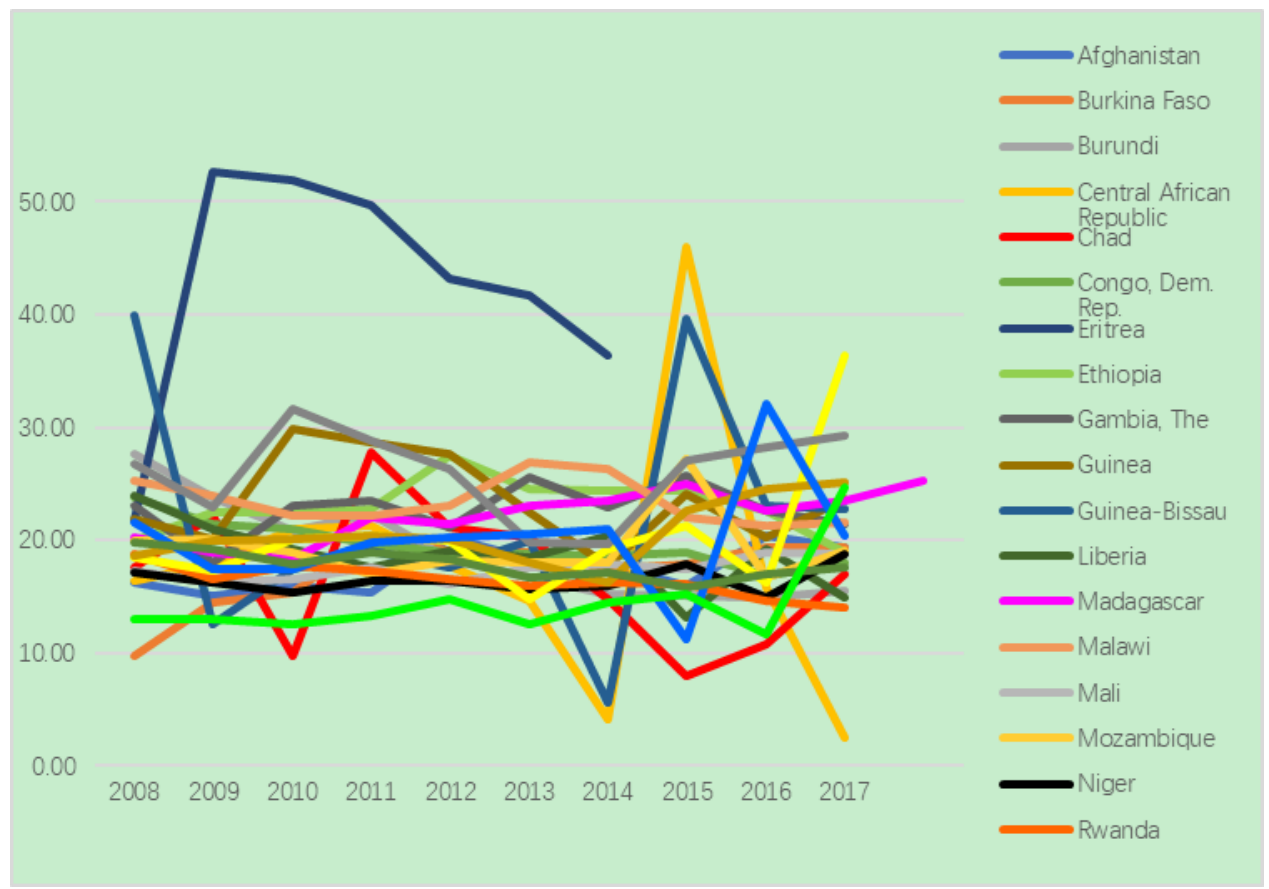

Figure 3. Financial Institutions Efficiency, 2008-2017

Note. The data has been sourced from World Bank (2021)

Figure 4 below indicates the stability of the financial institutions in the 25 countries analysed, although data on this measurement was available only for 11 countries. Between 2008 and 2017, there was a significant and positive increase in the stability of financial institutions, especially for Burkina Faso, Togo, Mali, and Burundi, but also for Guinea-Bissau, Niger, Uganda and Sierra Leone, although the last four countries mentioned had a steadier increase over the ten years.

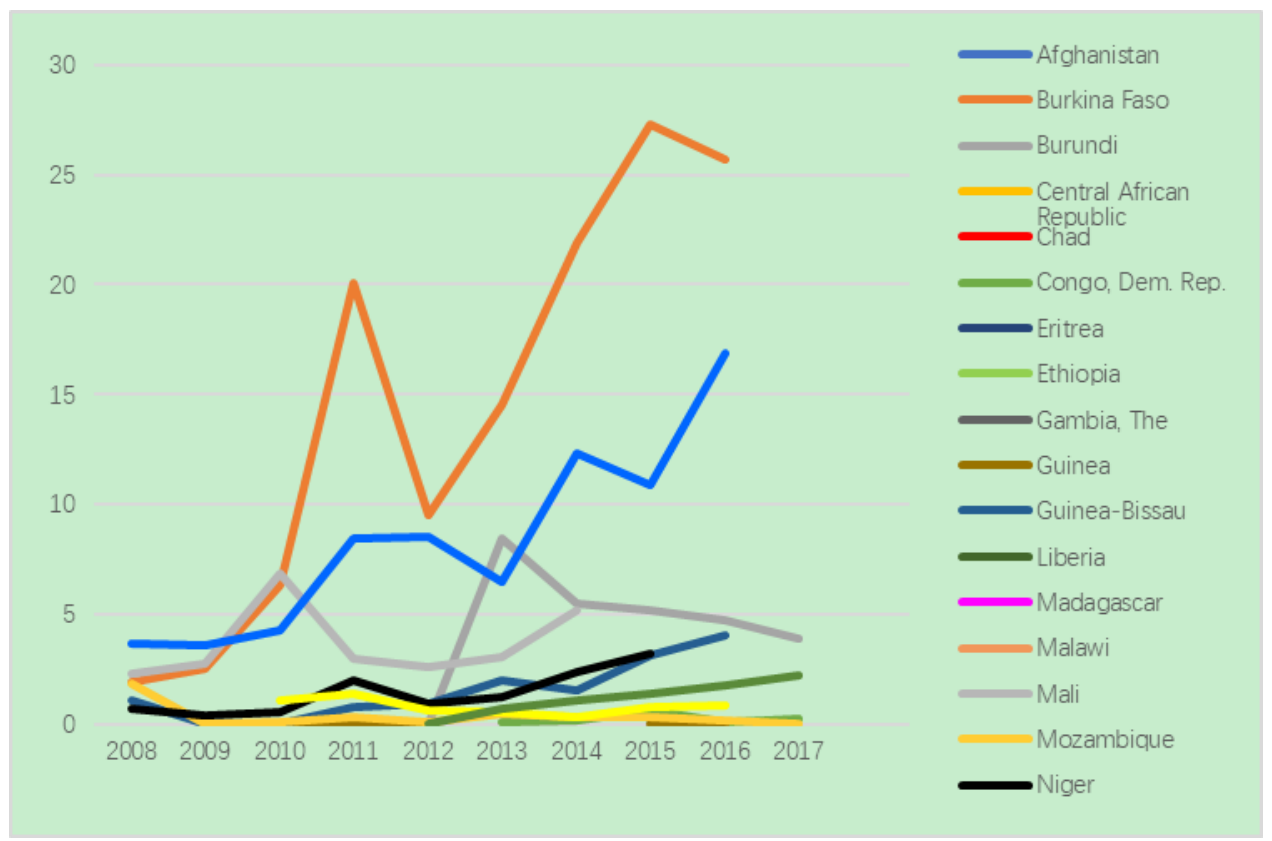

Figure 4. Financial Institutions Stability, 2008-2017

Note. Author's analysis based on World Bank data (2021)

Regarding financial markets in the developing countries, there are significant gaps in the data between 2008 and 2017, which limited the interpretation of the data. Figure 5 below shows a positive evolution of financial markets' access in Uganda, especially in 2014, but also in Afghanistan, Burundi and Malawi. Unfortunately, data was not 
available after 2015.

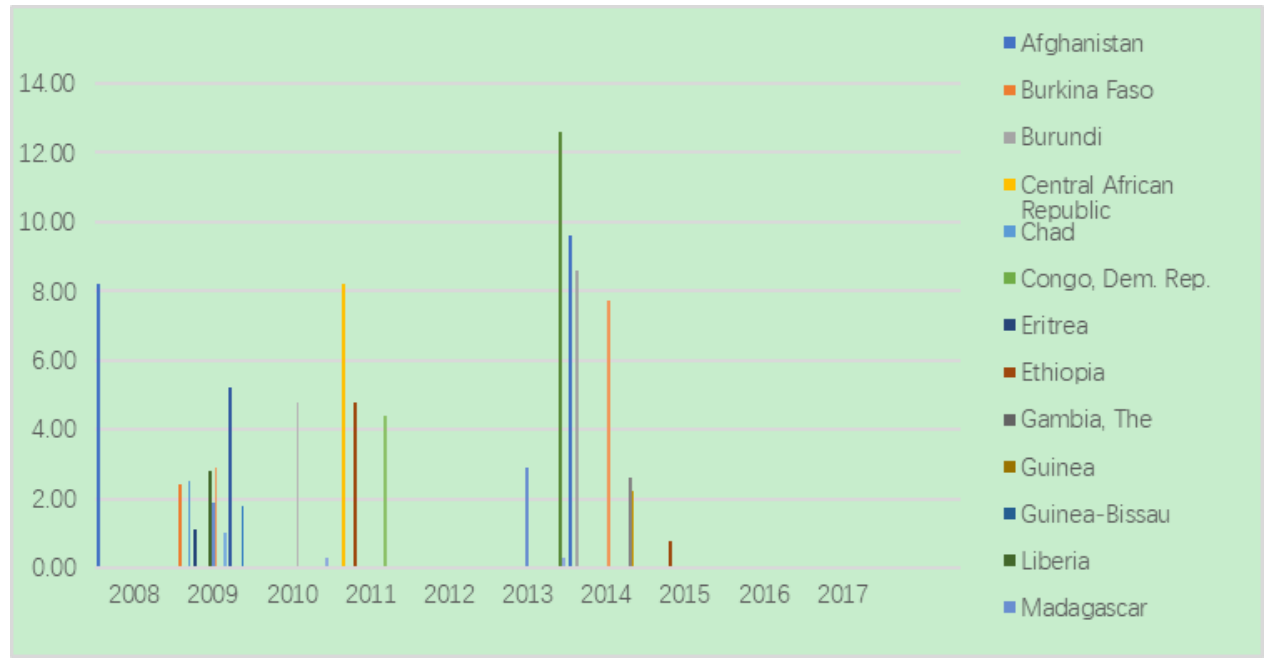

Figure 5. Financial Markets Access, 2008-2017

Note. Author's analysis based on World Bank data (2021)

Figure 6 below illustrated the depth of financial markets or their contribution in terms of size to the overall economy. Liberia again distanced itself from the other countries with a significantly higher level of financial markets' depth but in general, the developing countries analysed showed a positive, yet modest evolution in this area between 2008 and 2017.

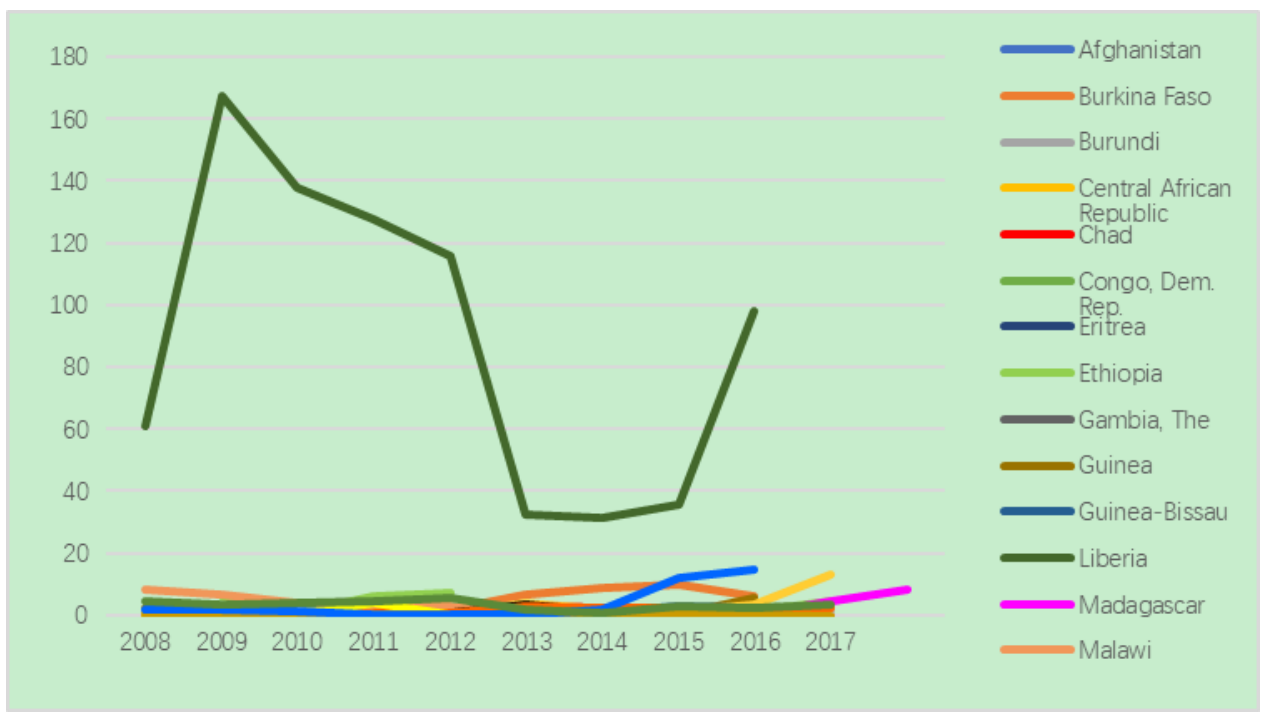

Figure 6. Financial Markets Depth, 2008-2017

Note. Author's analysis based on World Bank data (2021)

Lastly, Figure 7 below shows the efficiency of financial markets, meaning the extent to which all the available information is reflected in the market prices (Haralayya \& Aithal, 2021). Data is available only for two countries of the entire 25 countries sample, which vastly limits the accuracy and explanatory power of the independent variable, financial markets efficiency. Malawi shows a significant variation in its efficiency of financial markets between 2008 and 2012, followed by a lack of data, while Uganda had a negative evolution in the efficiency of its financial markets during the same timeframe, which was also followed by a lack in the data. 


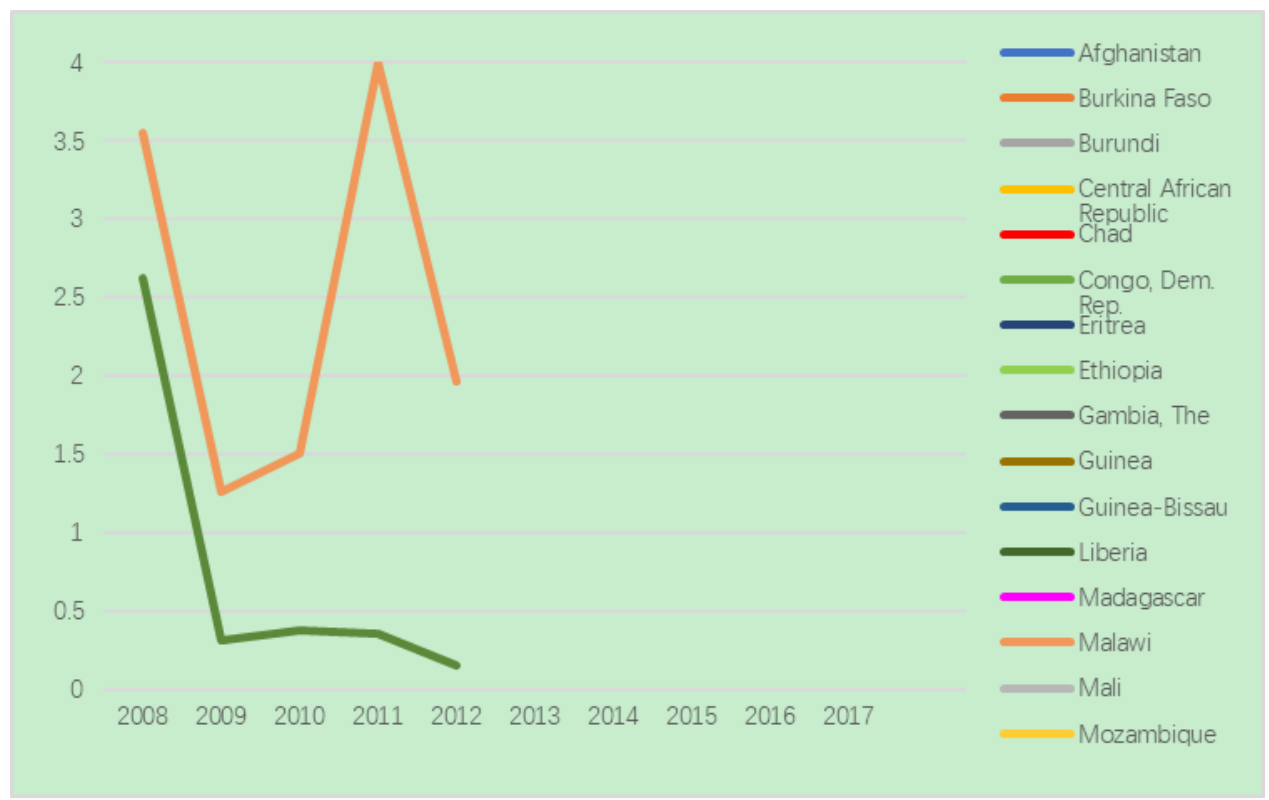

Figure 7. Financial Markets Efficiency, 2008-2017

Note. Author's analysis based on World Bank data (2021)

Moreover, Figure 8 below shows the evolution of the GDP growth per year in the 25 developing countries analysed. As noticed, the GDP growth in the selected countries varied from a maximum of 21.39 per cent increase in 2009 reported in Afghanistan to a minimum of -46.08 per cent drop in 2012 reported in South Sudan (World Bank, 2021). Three other significant drops in the level of GDP growth have been registered by the Central African Republic in 2013, of -36.39 per cent, by the Republic of Yemen in 2015, of -27.99 per cent, and by Sierra Leone also in 2015, of -20.60 per cent, although all of these changes were followed by significant increases in GDP growth in the next year (World Bank, 2021).

The average GDP growth was a 4.129 per cent increase in the ten years analysed, with a variation of +/- 6.55 per cent. This means that most countries, except for the outliers just described, have registered an average GDP growth that mostly varied between +10.679 per cent and -2.421 per cent in the 2008-2017 timeframe. Generally, this shows that developing countries in Africa and Asia for which data on GDP growth was available had a significant economic growth between 2008 and 2017. 


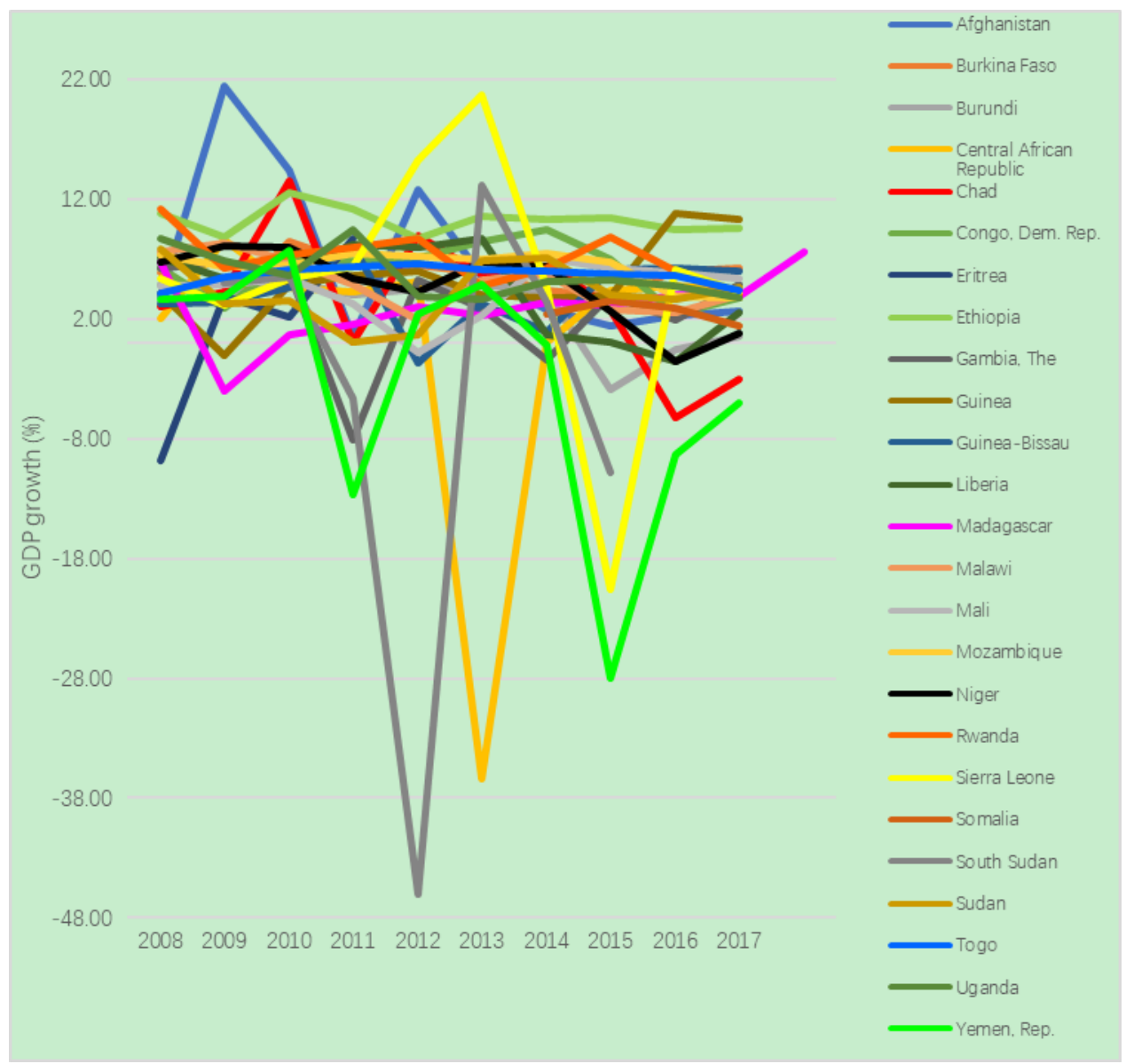

Figure 8. GDP growth (\%) yearly in the 25 selected countries

Note. Author's analysis based on World Bank data (2021)

The estimation of the two-way fixed effects model proposed in equation (1) above shows that the country and time fixed effects are statistically significant at a 10 per cent level of significance and that the financial institutions' access also has a statistically significant and positive impact on economic growth at all levels of significance, based on the p-value of the estimated coefficient, as shown in Table 3 below. This result indicates that a one-point increase in the aggregate index for access to financial products and services is linked with a 0.052 per cent increase in the annual GDP and that this result is influenced by the country and time.

The other explanatory variables, meaning the depth, efficiency and stability of financial institutions and the access, depth and efficiency of financial markets are not significantly linked with the evolution of GDP growth in the selected developing countries. This could be due to the gaps in the data which limited the explanatory power of these variables, especially those on the financial markets' access, depth and efficiency. There might also be other omitted variables from the model, given that the adjusted R-square for the estimated model is 0.034 . Also, the F-test indicates that the linear regression model selected with the independent variables proposed offers a better fit to the data than a model with no independent variables, meaning there is some correlation between the selected financial development indicators and economic growth. 
Table 3. Overview of regression analysis results

\begin{tabular}{lllll}
\hline & Coefficients & Standard Error & $t$ Stat & $P$-value \\
\hline Intercept & 5.451814307 & 1.653736758 & 3.296663922 & 0.001126561 \\
Country & -0.125906777 & 0.058338439 & -2.158213001 & 0.031903507 \\
Time & -0.293086786 & 0.142583873 & -2.055539518 & 0.040909101 \\
FI Access & 0.05255352 & 0.019508779 & 2.69383949 & 0.007561969 \\
FI Depth & 0.005784115 & 0.010440242 & 0.554021191 & 0.58008017 \\
FI Efficiency & 0.012920233 & 0.051503375 & 0.25086188 & 0.802135535 \\
FI Stability & 0.024773701 & 0.113556155 & 0.218162552 & 0.827487846 \\
FM Access & -0.061552981 & 0.257292756 & -0.239233247 & 0.811128895 \\
FM Depth & 0.006920907 & 0.03107278 & 0.222732158 & 0.823933411 \\
FM Efficiency & 0.533391717 & 0.991146479 & 0.538156295 & 0.59096787 \\
\hline
\end{tabular}

Note. Author's analysis

\subsection{The Perspective of Developing Countries}

As shown in the figures above based on the interpretation of the data from the World Bank, the financial development increased in the 25 selected countries during the 2008-2017 timeframe, especially in the areas of the financial institutions access, depth, efficiency, and financial markets access and less so in terms of the financial markets' depth and efficiency. This helps close the existing gap in the research around the evolution of financial development between 2008 and 2017 in developing countries and the impact of financial development on economic growth on the 25 selected developing economies, which, based on the World Bank (2020) definition and availability of data, these are low-income countries.

These insights can be correlated with the yearly GDP growth rate in the selected developing countries (Mhango, 2019). The access of the wider population and firms in the selected low-income countries in Africa and Asia has been shown to link positively and significantly with the economic growth in these countries measured by the GDP growth rate between 2008 and 2017.

\section{Discussion}

\subsection{Discussion and Interpretation of Results}

The results obtained in this study show that simply providing greater access to financial products and services to individual consumers and firms in developing countries in Africa and Asia could contribute significantly to increases in the economic growth of the region. In the ten years between 2008 and 2017, such access has been facilitated by an increased number of bank accounts opened by consumers, an increase in the number of bank branches, ATMs opened, as well as a higher number of credit and debit cards issued. The access to financial institutions also meant an increase in the sophistication of the products and services offered in these countries such as electronic payments and loans issued to firms and individual consumers.

There is great potential for the other areas of financial institutions and markets to develop which, coupled with improved access to the data, could potentially show a significant correlation with the economic growth of the developing countries. The overall political, economic and legislative frameworks must also be reformed in the majority of the developing countries analysed which would ease the financial development. The results obtained in this study have been summarised in Table 4 below where they have been linked to the current literature on the topic of financial development and its impact on economic growth with a focus on developing countries.

Linking back to the literature on the relationship between financial development and economic growth, with a focus on developing countries, the evidence of this paper supports the ideas of Erdoğan et al. (2020) and Ibrahim and Alagidede (2018) that the development of the financial sector has a significant impact on economic growth. The findings in this study also agree with the argument of Čihák et al. (2012) that the countries with more developed financial systems have higher GDP growth rates, as seen through the graphical analysis in the case of Guinea, Guinea-Bissau or Ethiopia to name just a few.

Also, Table 4 below shows the correspondence between the results of this study and similar findings in the extant research focusing on financial institutions access, although most studies in the literature do not examine financial 
development using the World Bank framework proposed in this paper based on the $4 \times 2$ matrix of financial institutions and financial markets access, depth, efficiency and stability and their relationship with economic growth.

Table 4. Synthesis of results linked to the literature

\begin{tabular}{ll}
\hline Result & Corresponding results in the literature \\
\hline $\begin{array}{l}\text { Positive and significant correlation between financial } \\
\text { institutions access and economic growth measured as } \\
\text { annual GDP growth }\end{array}$ & $\begin{array}{l}\text { Cheng and Degryse (2010) - positive link between } \\
\text { development and economic growth in China. }\end{array}$ \\
& $\begin{array}{l}\text { Rateiwa and Aziakpono (2017) - a strong relationship } \\
\text { between non-bank financial institutions and economic } \\
\text { growth in Egypt, South Africa but weak in Nigeria. }\end{array}$ \\
& $\begin{array}{l}\text { No significant correlation between financial institutions } \\
\text { depth, efficiency, stability or financial markets access, } \\
\text { depth, efficiency and economic growth. }\end{array}$ \\
& $\begin{array}{l}\text { linked wallh the growth of domestic capital stock in } \\
\text { insignificant. }\end{array}$
\end{tabular}

4.2 Concluding Remarks and Recommendations for Further Research

To conclude this study, financial development increased in the 25 selected countries particularly in the areas of financial institutions access, depth, efficiency, and financial markets access, but less so in the areas of financial markets depth and efficiency, as interpreted from World Bank data (2021). Also, financial development is positively and significantly linked with economic growth in developing countries through the access to financial institutions for people living in these countries.

Further research on the topic of financial development in low-income and developing countries is necessary to close the gap and find relevant connections and perhaps causality relations with other indicators. To avoid the limits of this study, it would be necessary to gain access to more data.

A general takeaway message is that the level of access to financial institutions has a positive impact on economic growth, as seen through this study on the selected 25 low-income countries between 2008 and 2017, while other variables of financial development did not have a significant statistical impact on economic growth for the selected countries in the respective timeframe.

\section{Acknowledgements}

The author would like to thank the two reviewers for their useful and constructive remarks; nevertheless, the author is solely responsible for any remaining errors.

\section{References}

Adams Jr, R. H. (2004). Economic growth, inequality and poverty: estimating the growth elasticity of poverty. World Development, 32(12), 1989-2014. https://doi.org/10.1016/j.worlddev.2004.08.006

Adeniyi, O., Ajide, B., \& Salisu, A. (2015). Foreign Capital Flows, Financial Development and Growth in Sub-Saharian Africa. Journal of Economic Development, 40(3), 85-103. https://doi.org/ 10.35866/caujed.2015.40.3.004

Anwar, S., \& Sun, S. (2011). Financial development, foreign investment and economic growth in Malaysia. Journal of Asian Economics, 22(4), 335-342. https://doi.org/10.1016/j.asieco.2011.04.001

BBC. (2018). Liberia profile - Timeline, 22 January. Retrieved October 22, 2021 from: https://www.bbc.com/news/world-africa-13732188

Bist, J. P. (2018). Financial development and economic growth: Evidence from a panel of 16 African and non-African low-income countries. Cogent Economics \& Finance, 6(1). 1-17. https://doi.org/10.1080/23322039.2018.1449780

Cheng, X., \& Degryse, H. (2010). The impact of bank and non-bank financial institutions on local economic growth in China. Journal of Financial Services Research, 37(2), 179-199. https://doi.org/10.1007/s10693-009-0077-4

Čihák, M., Demirgüç-Kunt, A., Feyen, E., \& Levine, R. (2012). Benchmarking financial systems around the world. World Bank policy research working paper, 6175. https://doi.org/10.1596/1813-9450-6175 
Čihák, M., Demirgüč-Kunt, A., Feyen, E., \& Levine, R. (2013). Financial development in 205 economies, 1960 to 2010 (No. w18946). National Bureau of Economic Research. https://doi.org/10.3386/w18946.

Daly, H. E. (1987). The economic growth debate: what some economists have learned but many have not. Journal of Environmental Economics and Management, 14(4), 323-336. https://doi.org/10.1016/0095-0696(87)90025-8

Dawson, P. J. (2008). Financial development and economic growth in developing countries. Progress in Development Studies, 8(4), 325-331. https://doi.org/10.1177/146499340800800402

Erdoğan, S., Yıldırım, D. Ç., \& Gedikli, A. (2020). Natural resource abundance, financial development and economic growth: an investigation on Next-11 countries. Resources Policy, 65, 101559. https://doi.org/10.1016/j.resourpol.2019.101559

Estrada, G. B., Park, D., \& Ramayandi, A. (2010). Financial development and economic growth in developing Asia. Asian Development Bank Economics Working Paper, 233. https://doi.org/10.2139/ssrn.1751833

Ezeibekwe, O. F. (2020). Financial development in developing countries. Global Economy Journal, 20 (3), 2050016. https://doi.org/10.1142/S2194565920500165

Fisher, I. (1930). Theory of interest: as determined by impatience to spend income and opportunity to invest it. Augustusm Kelly Publishers.

Haralayya, D., \& Aithal, P. S. (2021). Study on Productive Efficiency of Financial Institutions. International Journal of Innovative Research in Technology (IJIRT), 8(1), 159-16. https://doi.org/10.2139/ssrn.3860891

Haseeb, M., Wattanapongphasuk, S., \& Jermsittiparsert, K. (2019). Financial Development, Market Freedom, Political Stability, Economic Growth and C [O. sub. 2] Emissions: An Unexplored Nexus in ASEAN Countries. Contemporary Economics, 13(3), 363-375. https://doi.org/10.21203/rs.3.rs-843124/v1

He, L., Liu, R., Zhong, Z., Wang, D., \& Xia, Y. (2019). Can green financial development promote renewable energy investment efficiency? A consideration of bank credit. Renewable Energy, 143, 974-984. https://doi.org/10.1016/j.renene.2019.05.059

Klapper, L. (2015). First Credit Bureau Conference. Riga, Latvia. 13.1.15. Development Research Group, World Bank. Retrieved October 16, 2021 from: http://docplayer.net/13396703-First-credit-bureau-conference.html

Imai, K., \& Kim, I. S. (2021). On the use of two-way fixed effects regression models for causal inference with panel data. Political Analysis, 29(3), 405-415. https://doi.org/10.1017/pan.2020.33

Imam, P. A., \& Kolerus, M. C. (2013). West African Economic and Monetary Union: Financial Depth and Macrostability. International Monetary Fund. Retrieved November 10, 2021 from: https://www.imf.org/external/pubs/ft/dp/2013/afr1306.pdf

Ibrahim, M., \& Alagidede, P. (2018). Effect of financial development on economic growth in sub-Saharan Africa. Journal of Policy Modelling, 40(6), 1104-1125. https://doi.org/10.1016/j.jpolmod.2018.08.001

Kaldor, N., \& Mirrlees, J. A. (1971). A new model of economic growth. In Readings in the Theory of Growth (pp. 165-183). Palgrave Macmillan. https://doi.org/10.1007/978-1-349-15430-2_13

Kaur, H., Lechman, E., \& Marszk, A. (2017). Catalyzing Development through ICT Adoption. The Developing World Experience. Springer International Publishing. https://doi.org/10.1007/978-3-319-56523-1

Mhango, J. (2019). Financial Development and Economic Growth in South Africa. Master of Science, Nelson Mandela University. Retrieved October 16, 2021 from: https://core.ac.uk/download/pdf/270043632.pdf

Mishkin, F. S. (2009). Globalization and financial development. Journal of development Economics, 89(2), $164-169$. https://doi.org/10.1016/j.jdeveco.2007.11.004

Nastu, A., Stancu, S., \& Dumitrache, A. (2020). Measuring the Level of Financial Development of U.E. Member Countries. Proceedings of the International Conference on Applied Statistics, 2(1), 176-187. https://doi.org/10.2478/icas-2021-0020

Qamruzzaman, M., \& Jianguo, W. (2020). The asymmetric relationship between financial development, trade openness, foreign capital flows, and renewable energy consumption: Fresh evidence from panel NARDL investigation. Renewable Energy, 159, 827-842. https://doi.org/10.1016/j.renene.2020.06.069 
Quartey, P. (2008). Financial sector development, savings mobilization and poverty reduction in Ghana. In Financial development, institutions, growth and poverty reduction (pp. 87-119). Palgrave Macmillan. https://doi.org/10.1057/9780230594029_5

Ouyang, Y., \& Li, P. (2018). On the nexus of financial development, economic growth, and energy consumption in China: New perspective from a GMM panel VAR approach. Energy Economics, 71, 238-252. https://doi.org/10.1016/j.eneco.2018.02.015

Pedroni, P. (1997). Panel Cointegration. Asymptotic and finite sample properties of pooled time series tests with an application to the PPP hypothesis. New Results. Economics, Indiana University, Bloomington, IN. Retrieved October 21, 2021 from: https://web.williams.edu/Economics/pedroni/pc-revc.pdf

Popkova, E. G. (2018). Contradiction of economic growth in today's global economy: Economic systems competition and mutual support. Revista ESPACIOS, 39(01).

Rateiwa, R., \& Aziakpono, M. J. (2017). Non-bank financial institutions and economic growth: Evidence from Africa's three largest economies. South African Journal of Economic and Management Sciences, 20(1), 1-11. https://doi.org/10.4102/sajems.v20i1.1545

Scott, M. F. (1991). A new view of economic growth. Oxford University Press. https://doi.org/10.1093/0198287429.001.0001

Taivan, A., \& Nene, G. (2016). Financial development and economic growth: evidence from southern African development community countries. The Journal of Developing Areas, 50(4), 81-95. https://doi.org/10.1353/jda.2016.0154

Wang, P., Xu, L., \& Xu, Z. (2017). Financial development and the aggregate savings rates: A hump-shaped relationship. https://dx.doi.org/10.2139/ssrn.2085277

Wilson, A. B., Kerr, B. J., Bastian, N. D., \& Fulton, L.V. (2012). Financial performance monitoring of the technical efficiency of critical access hospitals: a data envelopment analysis and logistic regression modelling approach. Journal of Healthcare 200-213. https://doi.org/10.1097/00115514-201205000-00010

World Bank. (2020). Bank Regulation and Supervision a Decade after the Global Financial Crisis. Retrieved October 16 , 2021

from: https://www.worldbank.org/en/events/2019/11/28/global-financial-development-report-2019-2020-bank-regulat ion-and-supervision-a-decade-after-the-global-financial-crisis

World Bank. (2021). Financial Development. Retrieved October 16, 2021 from: https://www.worldbank.org/en/publication/gfdr/gfdr-2016/background/financial-development

Xu, Y., Zhao, X., Zhou, X., \& Yuan, L. (2021). Financial Structure and Capital Allocation Efficiency: An Empirical Analysis of China from 2005-2018. Applied Economics, 53(29), 3347-3358. https://doi.org/10.1080/00036846.2021.1877256

Yang, F. (2019). The impact of financial development on economic growth in middle-income countries. Journal of International Financial Markets, Institutions and Money, 59, 74-89. https://doi.org/10.1016/j.intfin.2018.11.008

\section{Copyrights}

Copyright for this article is retained by the author(s), with first publication rights granted to the journal.

This is an open-access article distributed under the terms and conditions of the Creative Commons Attribution license (http://creativecommons.org/licenses/by/4.0/). 